\title{
Tax Competition and Tax Structure in Open Federal Economies: Evidence from OECD Countries with Implications for the European Union
}

\author{
Timothy J. Goodspeed \\ Hunter College - CUNY \\ Department of Economics \\ 695 Park Avenue \\ New York, NY 10021 \\ USA \\ Telephone: 212-772-5434 \\ Telefax: 212-772-5398 \\ E-mail: timothy.goodspeed@hunter.cuny.edu
}

Revised: March, 1999

\begin{abstract}
Tax competition arguments suggest that governments that operate in an open economy (such as local governments) should not and will not rely on nonbenefit taxes, such as the income tax. Yet we observe reliance on income taxes by local governments in many countries, and such reliance changes over time. Evidence from a panel data set of 13 OECD countries over the period 1975-1984 suggests that competition between levels of government (resulting in a vertical fiscal externality) and between governments at the same level (resulting in a horizontal fiscal externality) provide some economic rationale for these changes. Moreover, the evidence indicates that the vertical and horizontal fiscal externalities interact. These results have some interesting implications for fiscal policy in the European Union, particularly as the EU continues to evolve. One implication for the EU is that enlargement that increases tax base disparities within the EU (and is not accompanied by an EU-level income tax) will tend to lower national income tax rates, although this must be qualified because it also depends on the mobility of the population. A second implication is that fiscal expansion of the EU to include an EU-level income tax may tend to lower the reliance of national governments on income taxes through the vertical externality, but may also tend to equalize tax bases across countries, and so increase reliance on national income taxes through the horizontal externality.
\end{abstract}

JEL Classification: $\mathrm{H} 87, \mathrm{H} 77, \mathrm{H} 1$

Keywords: Tax competition, Tax structure, Fiscal federalism, International taxation

I would like to thank two anonymous referees and Francois Bourguignon for excellent comments and Hassan ArvinRad, Howard Chernick, John Devereux, Bill Evans, Walter Hettich, Keith Heyen, Cem Karayalcin, Luis Locay, and Wallace Oates for comments and/or discussions on previous drafts. Any remaining errors are my own. Part of this research was undertaken while I was a Visiting Professor at the Universidad Carlos III de Madrid. I am also grateful for partial support for this research from Florida International University's Research Project Funding Program while I was an Assistant Professor there. 


\section{ZEW Summary}

Tax competition arguments suggest that governments that operate in an open economy (such as local governments) should not and will not rely on non-benefit taxes, such as the income tax. Yet we observe reliance on income taxes by local governments in many countries, and such reliance changes over time. Evidence from a panel data set of 13 OECD countries over the period 1975-1984 suggests that tax competition between levels of government (resulting in a vertical fiscal externality) and between governments at the same level (resulting in a horizontal fiscal externality) provide some economic rationale for changes in local tax rates within countries over time.

Evidence of vertical tax competition is observed in which higher national income tax rates lead to lower local income tax rates. Evidence of horizontal tax competition is found in two variables. First, a measure of mobility suggests that the more mobile the population, the lower are local income tax rates. Second, it is found that greater tax base disparities lead to lower local income tax rates. Moreover, the evidence indicates that the vertical and horizontal fiscal externalities interact. An increase in the national tax rate lowers local income tax rates through the vertical externality, but also lowers tax base disparities and hence increases local income tax rates through the horizontal externality. It is also found that redistributive grants from the national government affect the horizontal externality by lowering tax base disparities and hence increasing local income tax rates.

These results have some interesting implications for fiscal policy in the European Union, particularly as the EU continues to evolve. One implication for the EU is that member expansion that increases tax base disparities within the EU (and is not accompanied by an EU-level income 
tax) will tend to lower national income tax rates, although this must be qualified because it also depends on the mobility of the population. A second implication is that fiscal expansion of the EU to include an EU-level income tax may tend to lower the reliance of national governments on income taxes through the vertical externality, but may also tend to equalize tax bases across countries, and so increase reliance on national income taxes through the horizontal externality. 


\section{Introduction}

The degree to which local governments across the OECD countries rely on personal income taxes to finance their expenditures differs tremendously and changes over time. Table 1 shows that individual income tax revenue of local governments as a proportion of GNP (averaged over the 1975-1984 period) ranged from a low of zero or close to zero in countries such as the USA, the UK and the Netherlands to a high of .14 in Sweden and .12 in Denmark. ${ }^{1}$ Moreover, reliance on local income taxes within these countries changes over time, sometimes increasing as in Sweden and sometimes decreasing as in Norway. This is quite extraordinary because both normative and positive arguments suggest that governments that operate in an open economy environment, such as local governments, should not and will not rely on non-benefit taxes, such as the income tax.

The well-known argument holds that a taxed factor can migrate to avoid the tax in an open economy; this produces an excess burden (the normative argument) and may lead to zero tax rates in equilibrium (the positive argument). ${ }^{2}$ The traditional normative view can be found in Stigler (1957) and Oates (1972), for instance. The implications for redistributive tax policy in the European Union have been discussed in Sinn (1990), Persson and Tabellini (1992), and Cremer and Pestieau

${ }^{1} \mathrm{~A}$ similar ranking results if local income tax revenue is taken as a proportion of total local government revenues. For 1975, for instance, this proportion for Sweden is .51, .42 for Denmark, and zero for the UK.

${ }^{2}$ We concentrate on personal income taxes in this paper, but similar arguments are put forth in the literature on capital income taxation. For instance, Gordon (1986), Bond and Samuelson (1989), and Razin and Sadka (1991) show that capital income taxes may be competed to zero in an open economy. Two surveys of capital income taxation in an open economy are Giovannini (1990) and Keen (1992). 
(1996). ${ }^{3}$ Two notable surveys on redistribution and factor mobility are Cremer et. al. (1995) and Wildasin (1998).

This paper attempts to explain empirically changes in local income taxes over time by appealing to vertical and horizontal fiscal externalities that exist in an open federal economy. A theory of horizontal externalities has seen its modern development in the tax competition literature such as Wildasin (1988, 1989) and Zodrow and Mieszkowski (1986); Boadway and Keen (1996) investigate theoretical aspects of vertical externalities. Besley and Rosen (1998) estimate the impact of the vertical externality using data on the United States; Goodspeed (forthcoming) estimates the effect of both externalities using data from the OECD. This paper adds to this literature and the evidence indicates that these externalities interact. The results are related to fiscal policies in the European Union.

As background, fiscal externalities generally refer to a situation in which the tax rate set by one of the jurisdictions affects the tax revenues of the other jurisdiction. An example of a vertical fiscal externality is the case of two different levels of government that tax the same base. In this case, an increase in the tax rate of the national government will affect the tax base of a lower-level government. A horizontal fiscal externality may result when two governments at the same level tax a base that is mobile between the two jurisdictions. The tax rate set by any one of the jurisdictions is influenced by the fear that the mobile tax base will flee and leads to lower tax rates on mobile factors.

${ }^{3}$ Several papers in the recent special issue of the European Economic Review on The Domain of the State, such as Edwards and Keen (1996) and Picketty (1996), address related issues, as do several papers in a recent special issue of International Tax and Public Finance, summarized in Wildasin (1996). 
This paper first develops these arguments in a simple model that incorporates two levels of government and two governments at the lower-level. It is shown that tax base disparities as well as the degree of mobility of the taxed factor will influence the size of the horizontal fiscal externality. The paper then develops an econometric model to estimate the impact of the externalities. It is recognized in the empirical framework that the externalities may interact with each other. A panel data set on 13 OECD countries over the period 1975-1984 is used in the empirical estimation. Fixed effects are included; this is important in any cross-country study, and is particularly important here to control for different fiscal assignments.

The results consistently indicate that one influence on the horizontal externality, our measure of the mobility of the population, is negatively related to the local income tax rate. The measure of the vertical externality, the national income tax rate, is also negatively related to the local income tax rate. However, this result, as well as the results on a second influence on the horizontal externality, a tax base disparity measure, are influenced by various interaction effects. Theoretically, lower tax base disparities lessen the horizontal fiscal externality and so lead to higher local tax rates on mobile factors. The vertical fiscal externality may interact with the horizontal fiscal externality since a higher national tax rate may lower tax base disparities, and so through the horizontal externality lead to higher local income tax rates. Evidence consistent with this interaction effect is found with the implication that the vertical externality may be larger if tax bases are more equal. Higher tax base disparities are also found to lower local income tax rates when interaction terms with the national tax rate and grants are included. However, the impact of national taxes and grants on tax base disparities is such that tax base disparities result in no marginal effect evaluated at the average national tax rate and the average level of grants of the sample. 
These results have some interesting implications for fiscal policy in the European Union, particularly as the EU continues to evolve. This paper tries to understand changes in tax structure within an open federal economy by analyzing changes in the horizontal and fiscal externalities within those economies. To draw inferences for the EU, we need to project the results from the sets of open economies analyzed in this paper (local governments within a country) to the EU, where we view the EU as another set of open economies. Such an experiment needs to be done with caution, but the implications are of some interest.

One implication for the EU is that expansion to include Eastern and Central European countries or Turkey implies greater tax base disparities within the EU. ${ }^{4}$ Given the lack of an EUlevel income tax and relatively low grant levels, this will tend to lower national income tax rates according to the results of this paper. However, this also depends on the mobility of the population, and the degree of mobility of such populations to other countries is debatable.

A second implication is that fiscal expansion of the EU to include an EU-level income tax, as suggested in Sachs and Sala-I-Martín (1991) as a measure important to the viability of a common currency, has consequences for vertical and horizontal fiscal externalities as well. The vertical externality resulting from such a tax may tend to lower the reliance of national governments on income taxes (holding spending constant) according to the results of this paper. However, such a tax may also tend to equalize tax bases, and so increase reliance on national income taxes through the horizontal externality.

The rest of the paper is organized as follows. The next section develops the concepts of

${ }^{4}$ A recent paper by Baldwin, Francois, and Portes (1997) analyzes the trade impact of such an expansion. 
vertical and horizontal fiscal externalities in a simple theoretical framework. Section III describes the data and econometric framework. Section IV presents the empirical results and Section V concludes.

\section{Vertical and Horizontal Tax Competition in a Federal Economy}

A number of positive models, such as that of Hettich and Winer (1988) for instance, can be used to illustrate the effects of vertical and horizontal externalities on tax structure. The model must be one in which there are at least two levels of government, and in which the lower level of government consists of at least two jurisdictions. We develop here a simple positive model in which there is a national level of government that levies a tax on income at rate $\mathrm{t}^{\mathrm{n}}$, and two governments at the local level that also levy taxes on income at the rates $\mathrm{t}_{1}^{\mathrm{L}}$ and $\mathrm{t}_{2}^{\mathrm{L}}$, respectively. The national government will be assumed to be uninfluenced by changes in local tax structure because the national government is large and acts as a Stackelberg leader, as suggested in Besley and Rosen (1998) and Boadway and Keen (1996). We concentrate on the reaction of the local level of government to changes in variables that it takes as given throughout our discussion. In particular, the local government will react to changes in the national tax rate and will take into account the change in its tax base resulting from changes in its tax rate when choosing its tax rate.

To examine the local government's behavior with respect to these two factors, we first set up that government's optimization problem. We assume that there are two local governments and concentrate on the reaction function of jurisdiction 1. Assuming that preferences are single-peaked, we can apply the median voter theorem which implies that the government will satisfy the 
preferences of the median voter. ${ }^{5}$ We assume that the preferences of the median voter are defined over a private good, $\mathrm{X}$, the per-capita level of a publicly provided private good, $\mathrm{G}^{\mathrm{L}}$, and a national public good, $\mathrm{G}^{\mathrm{n}}$, and that preferences are additively separable:

$$
U\left(X, G_{1}^{L}, G^{n}\right)=u(X)+v\left(G_{1}^{L}\right)+w\left(G^{n}\right)
$$

Private before-tax income is assumed to be a negative function of both the national and local government tax rates to reflect the deadweight loss that results from taxation and hence is written as $\mathrm{y}\left(\mathrm{t}_{\mathrm{j}}^{\mathrm{L}}, \mathrm{t}^{\mathrm{n}}\right)$ for an individual who resides in $\mathrm{j}$. To arrive at after-tax income, taxes paid to both local and national governments are subtracted from before-tax income.

The local government is assumed to finance expenditures using a proportional income tax; hence, local government one's budget constraint is given by

$$
G_{1}^{L}=t_{1}^{L} y_{1}^{m}
$$

where $\mathrm{y}_{1}^{\mathrm{m}}$ is the per-capita tax base (mean income) of local government one. Furthermore, mobility of the tax base implies that mean income depends on the tax rate of local government two as well as local government one; hence, $\mathrm{y}_{1}^{\mathrm{m}}=\mathrm{y}_{1}^{\mathrm{m}}\left(\mathrm{t}_{1}^{\mathrm{L}}, \mathrm{t}_{2}^{\mathrm{L}}\right){ }^{6} \quad$ The national public good is also assumed to be financed by an income tax, but income is immobile for the national government. However, the national tax base, Y, will depend on all three tax rates because of the usual deadweight loss that

\footnotetext{
${ }^{5}$ Single peaked preferences are a feature of a wide class of migration models that assume a single crossing property of indifference curves such as Westhoff (1977), Epple, Filimon and Romer (1984), Goodspeed (1989, 1995, 1998a), Epple and Romer (1991), and Fernandez and Rogerson (1996, 1998).

${ }^{6}$ The specific way in which mean income depends on these tax rates will depend on the equilibrium migration adjustments in the particular model under study.
} 
results from taxation, so the national government's budget constraint is

$$
G^{n}=t^{n} Y\left(t_{1}^{L}, t_{2}^{L}, t^{n}\right)
$$

The problem of the local government is to choose the local tax rate to maximize the median voter's utility subject to the median voter's budget constraint, the local government's budget constraint, and the national government's budget constraint:

$$
\begin{gathered}
\max _{t_{1}^{L}} u(X)+v\left(G_{1}^{L}\right)+w\left(G^{n}\right) \\
\text { s.t. } \quad X=y\left(t_{1}^{L}, t^{n}\right)\left(1-t_{1}^{L}-t_{1}^{n}\right) \\
G_{1}^{L}=t_{1}^{L} y_{1}^{m}\left(t_{1}^{L}, t_{2}^{L}\right) \\
G^{n}=t^{n} Y\left(t_{1}^{L}, t_{2}^{L}, t^{n}\right)
\end{gathered}
$$

where $\mathrm{y}\left(\mathrm{t}_{1}^{\mathrm{L}}, \mathrm{t}^{\mathrm{n}}\right), \mathrm{Y}\left(\mathrm{t}_{1}^{\mathrm{L}}, \mathrm{t}_{2}^{\mathrm{L}}, \mathrm{t}^{\mathrm{n}}\right)$, and $\mathrm{y}_{1}^{\mathrm{m}}\left(\mathrm{t}_{1}^{\mathrm{L}}, \mathrm{t}_{2}^{\mathrm{L}}\right)$ are functions as noted above. Substituting the constraints into the objective function and differentiating yields the first order condition

$$
-u_{X}\left(y\left(t_{1}^{L}, t^{n}\right)-\frac{\partial y}{\partial t_{1}^{L}}\left(1-t_{1}^{L}-t_{1}^{n}\right)\right)+v_{G^{L}}\left(y_{1}^{m}\left(t_{1}^{L}, t_{2}^{L}\right)+t_{1}^{L} \frac{\partial y_{1}^{m}}{\partial t_{1}^{L}}\right)+w_{G^{n}} \frac{\partial Y}{\partial t_{1}^{L}} t^{n}=0
$$

The term $\partial \mathrm{y}_{1}^{\mathrm{m}} / \partial \mathrm{t}_{1}^{\mathrm{L}}$ is the fiscal externality discussed in the horizontal tax competition literature such as in Wildasin $(1988,1989)$ and Zodrow and Mieszkowski (1986). That literature argues that the fiscal externality term is negative and that tax base mobility imposes a fear that non-benefit taxes will drive out the mobile tax base, and leads to lower tax rates. Notice that if $\partial \mathrm{y}_{1}^{\mathrm{m}} / \partial \mathrm{t}_{1}^{\mathrm{L}}$ is negative, the price of local public services is higher than it would be if the decisive voter ignored the mobility 
of the tax base, and so the optimal tax rate is lower than it would be otherwise.

Clearly, factors that influence the size of this fiscal externality will alter the equilibrium tax rate. One factor that influences the size of the fiscal externality is the mobility of the tax base: greater mobility implies a greater response of the base to a change in the tax rate. This has been suggested in Wildasin (1991), for example. A second factor that influences the size of the fiscal externality are tax base disparities (Oates, 1972; Goodspeed, 1989, 1995). We can show this with the following definition and propositions. Since the tax base disparity argument concerns migration of the tax base, we simplify the analysis by assuming away any labor supply deadweight loss in the propositions.

Definition 1: The income tax base disparity between two jurisdictions is the difference in their mean incomes. $^{7}$

Proposition 1: Suppose there is no labor supply distortion. If $\mathrm{y}_{1}^{\mathrm{m}}=\mathrm{y}_{2}^{\mathrm{m}}$ in equilibrium, then $\partial \mathrm{y}_{1}^{\mathrm{m}} / \partial \mathrm{t}_{1}^{\mathrm{L}}$ $=0$.

Proof: Suppose $\partial \mathrm{y}_{1}^{\mathrm{m}} / \partial \mathrm{t}_{1}^{\mathrm{L}} \neq 0$. This implies that an individual with income $\mathrm{y} \neq \mathrm{y}_{1}^{\mathrm{m}}$ must move from one jurisdiction to the other. But this implies $\mathrm{y}_{1}^{\mathrm{m}} \neq \mathrm{y}_{2}^{\mathrm{m}}$, a contradiction.

Proposition 2: If $\partial \mathrm{y}_{1}^{\mathrm{m}} / \partial \mathrm{t}_{1}^{\mathrm{L}}<0$, the optimal tax rate is higher the smaller is $\partial \mathrm{y}_{1}^{\mathrm{m}} / \partial \mathrm{t}_{1}^{\mathrm{L}}$.

Proof: Examination of first order condition (5).

It is worthwhile explaining the intuition of these propositions. The fiscal externality results from the fact that an increase in a jurisdiction's tax rate reduces the jurisdiction's tax base and hence increases the jurisdiction's tax price. The optimal tax rate is thus lower because of this externality. Proposition 2 shows that the smaller is the externality, the less is the increase in the jurisdiction's tax price and hence the higher is the optimal tax rate. Proposition 1 shows that if there is no tax base disparity in equilibrium, there is no horizontal fiscal externality.

${ }^{7}$ Here the focus is on income tax base disparities, but the argument applies generally to any tax, including, for instance, sales taxes. 
For the empirical work, we are also interested in the effect of the vertical externality, as reflected in the slope of the reaction function with respect to $\mathrm{t}^{\mathrm{n}}$. This can be derived by differentiating (5) with respect to $t^{\mathrm{n}}$ :

$$
-u_{X}\left(\frac{\partial y}{\partial t^{n}}+\frac{\partial y}{\partial t_{1}^{L}}\right)+u_{X X}\left(y-\frac{\partial y}{\partial t^{n}}\left(1-t_{1}^{L}-t^{n}\right)\right)\left(y-\frac{\partial y}{\partial t_{1}^{L}}\left(1-t_{1}^{L}-t^{n}\right)\right)+w_{G^{n}} \frac{\partial Y}{\partial t_{1}^{L}}+w_{G^{n} G^{n}} t^{n} \frac{\partial Y^{2}}{\partial t_{1}^{L} \partial t^{n}}
$$

As in Boadway and Keen (1996) and Besley and Rosen (1998), the slope of the reaction function with respect to $\mathrm{t}^{\mathrm{n}}$ can be positive or negative. It is thus an empirical matter to determine the sign.

\section{Econometric Framework and Data}

The theoretical section develops two externality concepts that may affect the choice of the local tax rate on income. A vertical externality may result if the national and local governments tax the same base. A horizontal externality may result from horizontal tax competition in an open economy. We also showed that the horizontal externality will be exacerbated by greater tax base disparities as well as greater tax base mobility.

In addition to the direct effects of tax base mobility and disparity on the fiscal externality that we have noted, there are some complex interactions that need to be taken into account. First, the vertical and horizontal externalities may themselves interact. A change in the national tax rate may affect the distribution of income and thereby tax base disparities. A higher national tax rate may be expected to reduce inequality and possibly tax base disparities. This indirect effect on tax base disparities would lead to a higher optimal local tax rate through the horizontal externality, as discussed in the theoretical section. A second possible interaction may result from central 
government grants, which we have ignored in the theoretical section, but are often suggested as a means to try to even out tax base disparities. To the extent that grants are used for this purpose, higher grant levels would be expected reduce tax base disparities. The lower tax base disparities would lead to higher local income taxes, as discussed in the theoretical section.

Other variables may also affect the optimal local tax rate. Inclusion of the level of local government spending is warranted from the local government budget constraint. ${ }^{8}$ Differences in fiscal assignment (or other institutional differences) are likely across countries. To control for this, it is important to include country-specific fixed effects.

The basic estimating equation is therefore

$$
t_{c t}^{L}=b_{0}+b_{1} t_{c t}^{n}+b_{2} M_{c t}+b_{3} B_{c t}+b_{4} G_{c t}^{L}+b_{5} B_{c t} * t_{c t}^{n}+b_{6} B_{c t} * g_{c t}+b_{7} D_{c}+\epsilon_{c t}
$$

where the subscript $c t$ refers to country $\mathrm{c}$ in year $\mathrm{t}, \mathrm{t}_{\mathrm{ct}}^{\mathrm{L}}$ refers to the local income tax rate in country $\mathrm{c}$ in year $\mathrm{t}, \mathrm{t}_{\mathrm{ct}}^{\mathrm{n}}$ refers to the national income tax rate in country $\mathrm{c}$ in year $\mathrm{t}$ and reflects the vertical externality, $M_{c t}$ is a variable that measures tax base mobility, $B_{c t}$ is a variable that measures the tax base disparity influence on the horizontal externality, $g_{c t}$ measures grants in country $c$ in year $t, D_{c}$ are country specific dummy variables, and $\epsilon_{\mathrm{ct}}$ is a random error term.

Since public spending is endogenously chosen, simultaneous equation problems may result. This can be corrected either by an instrumental variables approach or by estimation of a simultaneous

${ }^{8}$ There could be also be interactions with other local taxes which suggests inclusion of a variable reflecting local taxes on other bases. However, inclusion of such a variable makes the estimating equation close to an identity; the result is that the coefficient on total spending is reduced and becomes insignificant in most specifications. Moreover, the coefficient on other local taxes is insignificant, and the results for the other variables are unaffected. The reported results therefore exclude the direct effect of local taxes on other bases, but local taxes on other bases are included as an instrument for public spending. 
system of equations. The estimation of a simultaneous system only converged when fixed effects were omitted. Since this omission renders the results from this technique suspect, these results are not reported. Rather, an instrumental variable technique is used to obtain a predicted value for local public spending.

We assembled a data set of 13 OECD countries for the period 1975-1984. Monetary figures are converted to dollars where necessary using OECD purchasing power parity measures. The OECD (1986) describes the state and local tax systems of these countries.

Tax Rates and the Vertical Fiscal Externality. The local income tax rate, $\mathrm{t}^{\mathrm{L}}$, is computed as total local personal income tax revenue divided by GNP. ${ }^{9}$ It therefore represents an average local income tax rate for a country. Local income taxes are zero for some countries for some years. This means that the dependent variable takes on a value of zero at times and least squares estimates are biased. For this reason, Tobit estimation is performed.

A variable that represents the vertical externality is the income tax rate of higher level governments, $\mathrm{t}^{\mathrm{n}}$. This variable is similarly constructed as total national and state income tax revenue divided by GNP. ${ }^{10}$ The data used to construct all of these tax rates come from the OECD (1989, various years).

Measuring the Horizontal Fiscal Externality. The empirical difficulty for the horizontal fiscal externality is to find a measure for $\mathrm{B}_{\mathrm{ct}}$, tax base disparity, and $\mathrm{M}_{\mathrm{c}}$, tax base mobility.

9 The effective local tax rate will be lower if the central government allows individuals to deduct local taxes in determining the federal tax base. However, deductibility is a unique feature of the United States, and hence is not considered.

10 The national tax rate may therefore partially reflect revenue needed for grants given to local governments. 
The ideal measure for $\mathrm{B}_{\mathrm{ct}}$, given in Definition 1 , is the difference between local government mean incomes of a country. Such data are unavailable, however. We will use a national inequality measure, the national difference between the percentage of income received by the poorest twenty percent of the population and that received by the richest twenty percent, to proxy for regional income disparities. Data in Larin and McNichol (1997) for the United States indicates that this is a reasonable approximation as regional income disparities closely follow national income disparities. It is also consistent with theoretical models that generate an equilibrium through a single-crossing property of indifference curves, such as those noted in footnote 5 . In these models, an equilibrium results in which the national distribution of incomes of a country is partitioned to obtain the regional distribution of incomes; an increase in the variance of the national distribution of income would then be reflected in the partition borders and regional income distributions.

$\mathrm{M}_{\mathrm{ct}}$, tax base mobility, is measured by a poverty index, the proportion of income received by the poorest twenty percent of the population. The greater is this index, the lower is the poverty rate. The lower is the poverty rate, the more mobile is expected to be the population. ${ }^{11}$

These variables are constructed from a new data set on income inequality across countries over time constructed by Deininger and Squire (1996). This is an important advance over previous work in public economics that uses data on income distributions (e.g. Kristov, Lindert, and McClelland, 1992) because it allows the inclusion of country-specific fixed effects. This is

${ }^{11}$ This interpretation is suggested theoretically in the work of Wildasin (1991), for instance. As noted in Goodspeed (forthcoming), another interpretation comes from yardstick competition models (Besley and Case, 1995). A lower poverty rate might also facilitate easier or more informed comparisons across jurisdictions. Yardstick competition models suggest that voter comparisons result in pressure for each jurisdiction to provide services at the lowest cost. Hence, easier or more informed comparisons among jurisdictions results in greater pressure and a lower tax rates. 
particularly important in cross-country work on federal systems to control for differences in fiscal assignments. Even in the Deininger and Squire data, there remain a few missing values for some years for some countries; these were filled in by interpolation.

Local Government Spending. Spending by local governments, $\mathrm{G}^{\mathrm{L}}$, is defined as total local revenue per capita. The data used to construct this variable come from the OECD (various years).

\section{Empirical Results}

Table 3 presents the results. Generally, the results with respect to the vertical externality indicate that the local tax rate falls the higher is the national tax rate, though this result needs to be qualified once the interaction with the horizontal externality is added. With respect to the horizontal externality, the results consistently indicate that the lower is our measure of mobility, the poverty rate, the higher is the local income tax rate. Our measure of tax base disparities is not significant unless either of the interaction terms are included. Once these are included, however, a negative association between tax base disparities and local income tax rates is found. The interaction terms indicate that this association must be qualified, and the total effect depends on the level of grants and the national tax rate.

Turning to a more detailed discussion of the results, column 1 of Table 3 gives the results with no interaction terms, column 2 includes an interaction of $\mathrm{t}^{\mathrm{n}}$ and $\mathrm{B}$, and column 3 adds to this an interaction of B and grants. The first column results are similar to results reported in Goodspeed (forthcoming), except that the results include a measure of tax base disparities. The results indicate a negative relationship between the national tax rate and the local tax rate; the coefficient of -.17 
implies an elasticity of -.42 computed at the mean. The coefficient on the poverty index is also negative and significant, and is interpreted as indicating that increased mobility leads to lower local income tax rates. The implied elasticity is 1.1 evaluated at the means. The tax base disparity measure is insignificant in the first column regression. Interaction terms are included in the next two columns and are important in establishing the significance of the tax base disparity measure.

The second column includes an interaction term of the tax base disparity measure and the national income tax rate to reflect the possibility that a higher national income tax rate lowers tax base disparities and thereby indirectly increases local income tax rates. Two interesting changes result. First, the tax base disparity measure becomes significant, and indicates that lower tax base disparity results in higher local income tax rates. The implied elasticity of the coefficient is a rather high -3.0. The interaction term indicates that the impact of a change in the national income tax rate on the local income tax rate is indeed affected by the level of tax base disparities. The greater are tax base disparities, the less negative is the impact of higher national income tax rates on local income tax rates. This is consistent with the hypothesis that higher national income tax rates tend to reduce tax base disparities and thereby indirectly increase local income tax rates. Computed at the average value of tax base disparities of the sample, the marginal effect of higher national income taxes is negative, but the coefficient is reduced from -.17 of column 1 to -.046 . More important for the European Union than the average value is the implication that the degree to which higher national tax rates impact local tax rates depends on the degree to which national tax rates change inequality and thereby tax base disparities. If tax base disparities are small (so that the interaction term is small) higher national tax rates have a much larger negative impact on local tax rates. On the other hand, if tax base disparities are large, the interaction term can be large enough that it offsets the 
negative vertical externality, and the total impact of the national tax rate on the local tax rate can be positive.

The third column adds an interaction of grants and tax base disparity to reflect the possibility that higher grant levels reduce tax base disparities and hence lead to higher local income taxes. This interaction term is found to be significant as well, and does not change much the other coefficients. The marginal effect of a change in tax base disparity depends on the value of both interaction terms. Evaluated at the means, the marginal effect is found to be -.005 , negative, but close to zero. More important, perhaps, is the recognition that the marginal impact of tax base disparities depends on the level of grants and on the national tax rate, both of which also impact tax base disparities. If both grants and the national tax rate are low so that both interaction terms are small, tax base disparities can significantly impact the local tax rate.

\section{Conclusion and Implications for the European Union}

Tax competition theories suggest that governments that operate in open economies should not and will not rely on non-benefit taxes. The argument is that the taxed factor can migrate to avoid payment. This creates an additional source of excess burden and many theoretical models predict zero tax rates in equilibrium. Yet, local governments across OECD countries, which can be thought of as sets of small open economies, vary widely in their use of income taxes, and their reliance varies over time. This paper suggests that changes in vertical and horizontal externalities that result from tax competition provide some economic rationale for changes in local income taxes over time.

Both horizontal and vertical fiscal externalities generally refer to a situation in which the tax 
rate set by one jurisdiction affects the tax revenues of the another jurisdiction. A vertical fiscal externality may result when two different levels of government tax the same base. An increase in the tax rate of the national government will affect the tax base of a lower-level government. A horizontal fiscal externality may result when two governments of the same level tax a base that is mobile between the two jurisdictions. The tax rate set by any one of the jurisdictions is influenced by the fear that the mobile tax base will flee and leads to lower tax rates on mobile factors. This paper first develops these arguments in a simple theoretical model that incorporates two levels of government and two governments at the lower-level. Furthermore, it is shown that tax base disparities as well as the degree of mobility of the taxed factor will influence the size of the horizontal fiscal externality.

An econometric model is developed to estimate the impact of the externalities. The empirical framework recognizes that the externalities may interact with each other, which turns out to have some importance in the estimated effects. A panel data set of 13 OECD countries over the period 1975-1984 is used in the empirical estimation. Importantly, fixed effects are included to control for cross-country differences, and particularly different fiscal assignments.

The results consistently indicate that one indication of the horizontal externality, our measure of the mobility of the population, is negatively related to the local income tax rate. The national income tax rate is also negatively related to the local income tax rate. However, this result, as well as the results on the tax base disparity measure of the horizontal externality, are influenced by various interaction effects. A higher national tax rate may lower tax base disparities, and so through the horizontal externality lead to higher local income tax rates. Evidence consistent with this is found, and the evidence indicates that the vertical externality may be larger if tax bases are more 
equal. Higher tax base disparities are also found to lower local income tax rates when interaction terms with the national tax rate and grants are included. However, the impact of national taxes and grants on tax base disparities is such that tax base disparities result in no marginal effect evaluated at the average national tax rate and the average level of grants of the sample.

These results have some interesting implications for fiscal policy in the European Union, particularly as the EU continues to evolve. To draw inferences from this study for the EU, we need to project the results from the sets of open economies analyzed in this paper (local governments within a country) to the EU, where we view the EU as another set of open economies. Such an experiment needs to be done with caution, but the public policy implications are of some interest.

One implication for the EU is that expansion to include Eastern and Central European countries or Turkey implies greater tax base disparities within the EU. Given the lack of an EU-level income tax and relatively low grant levels, this will tend to lower national income tax rates according to the results of this paper. However, this must be qualified because it also depends on the mobility of the population, and the degree of mobility of populations that become new EU members is debatable.

A second implication is that fiscal expansion of the EU to include an EU-level income tax, as suggested in Sachs and Sala-I-Martín (1991) as a measure important to the viability of a common currency, has consequences for vertical and horizontal fiscal externalities as well. The results of this study indicate that such a tax may tend to lower the reliance of national governments on income taxes (holding spending constant). However, an EU-level income tax may also tend to equalize tax bases across countries, and so increase reliance on national income taxes through the horizontal externality. 
Table 1

Local Individual Income Tax Revenue as Proportion of GNP

\begin{tabular}{|c|c|c|c|c|}
\hline Country & 1975 & 1984 & $\begin{array}{c}\text { Mean } \\
(1975-1984)\end{array}$ & $\begin{array}{c}\text { Standard Deviation } \\
\quad(1975-1984)\end{array}$ \\
\hline Sweden & .1169 & .1509 & .1427 & .0131 \\
\hline Denmark & .1052 & .1321 & .1188 & .0110 \\
\hline Finland & .0871 & .0866 & .0868 & .0049 \\
\hline Norway & .0877 & .0715 & .0853 & .0087 \\
\hline West Germany & .0189 & .0241 & .0201 & .0008 \\
\hline Austria & .0163 & .0151 & .0159 & .0005 \\
\hline France & .0061 & .0060 & .0055 & .0004 \\
\hline USA & 0 & .0016 & .0009 & .0008 \\
\hline Netherlands & .0008 & 0 & .0002 & .0003 \\
\hline Australia & 0 & 0 & 0 & 0 \\
\hline Canada & 0 & 0 & 0 & 0 \\
\hline Ireland & 0 & 0 & 0 & 0 \\
\hline UK & 0 & 0 & 0 & 0 \\
\hline
\end{tabular}

Source: Author's calculations from data in OECD (various years, 1989). 
Table 2

Summary Statistics

\begin{tabular}{|l|l|l|l|l|}
\hline Variable & Mean & $\begin{array}{l}\text { Standard } \\
\text { Deviation }\end{array}$ & Minimum & Maximum \\
\hline $\mathrm{t}^{\mathrm{L}}$ & 0.037 & 0.0505 & 0 & 0.1566 \\
$\mathrm{t}^{\mathrm{n}}$ & 0.090 & 0.0303 & 0.026 & 0.143 \\
$\mathrm{~B}$ & -0.3887 & .072 & -0.4948 & -.2673 \\
$\mathrm{~g}$ & 0.037 & 0.0298 & 0.0025 & 0.1196 \\
$\mathrm{M}$ & 0.066 & 0.0147 & .0393 & .1097 \\
$\mathrm{G}^{\mathrm{L}}$ & 1385 & 1026 & 144 & 4588 \\
\hline
\end{tabular}

Data sources: OECD (1989, various years) and Deininger and Squire (1996). 
Table 3

Tobit Regression Results

(dependent variable: $\mathrm{t}^{\mathrm{L}}$, local income tax revenue / GNP)

\begin{tabular}{|c|c|c|c|}
\hline \multirow[b]{2}{*}{ Constant } & \multicolumn{3}{|c|}{ Estimates } \\
\hline & $\begin{array}{l}0.0489 \\
1.281\end{array}$ & $\begin{array}{l}0.1555 \\
2.987\end{array}$ & $\begin{array}{l}0.1277 \\
2.401\end{array}$ \\
\hline $\begin{array}{l}\mathrm{t}^{\mathrm{n}} \\
\text { national income tax rate }\end{array}$ & $\begin{array}{l}-0.1679 \\
-2.149\end{array}$ & $\begin{array}{l}-1.4251 \\
-3.254\end{array}$ & $\begin{array}{l}-1.203 \\
-2.695\end{array}$ \\
\hline $\begin{array}{l}\text { M } \\
\text { mobility }\end{array}$ & $\begin{array}{l}-0.6256 \\
-3.447\end{array}$ & $\begin{array}{l}-0.8605 \\
-4.449\end{array}$ & $\begin{array}{l}-0.7536 \\
-3.816\end{array}$ \\
\hline $\begin{array}{l}\text { B } \\
\text { tax base disparity }\end{array}$ & $\begin{array}{l}0.02143 \\
0.267\end{array}$ & $\begin{array}{l}0.2866 \\
2.382\end{array}$ & $\begin{array}{l}0.23176 \\
1.902\end{array}$ \\
\hline $\begin{array}{l}\hat{G}^{\mathrm{L}} \text { local per capita expenditure } \\
\text { (instrumental variables estimate) }\end{array}$ & $\begin{array}{l}0.000006 \\
3.002\end{array}$ & $\begin{array}{l}0.000004 \\
2.012\end{array}$ & $\begin{array}{l}0.000005 \\
2.653\end{array}$ \\
\hline $\begin{array}{l}\mathrm{B} * \mathrm{t}^{\mathrm{n}} \\
\text { tax base disparity } * \text { national tax rate }\end{array}$ & & $\begin{array}{l}-3.5476 \\
-2.894\end{array}$ & $\begin{array}{l}-2.9287 \\
-2.342\end{array}$ \\
\hline $\begin{array}{l}\mathrm{B}^{*} \mathrm{~g}: \\
\text { tax base disparity * grants per capita }\end{array}$ & & & $\begin{array}{l}0.75055 \\
1.99\end{array}$ \\
\hline Country Dummies Included & Yes & Yes & Yes \\
\hline$\sigma$ & $\begin{array}{l}0.0054 \\
(12.6)\end{array}$ & $\begin{array}{l}.0052 \\
(12.7)\end{array}$ & $\begin{array}{l}0.0051 \\
(12.7)\end{array}$ \\
\hline Log of Likelihood Function & 302.9 & 307.2 & 309.2 \\
\hline
\end{tabular}

Notes for Table 3: The instrumental variables regression for $\mathrm{G}^{\mathrm{L}}$ yielded the following results:

$$
\mathrm{G}_{\mathrm{ct}}^{\mathrm{L}}=\underset{(-1.62)}{-1357.3}+\underset{(1.56)}{.0729 \mathrm{Y}_{\mathrm{ct}}}+\underset{(8.04)}{18351 \tau_{\mathrm{ct}}^{\mathrm{L}}}+\underset{(11.8)}{20123 \mathrm{~g}_{\mathrm{ct}}}+\mathrm{b}_{4} \mathrm{D}_{\mathrm{c}} \mathrm{R}^{2}=.97
$$

where $\mathrm{Y}_{\mathrm{ct}}$ is GDP per capita, $\tau^{\mathrm{L}}{ }_{\mathrm{ct}}$ is the tax rate on bases other than income, $\mathrm{g}_{\mathrm{ct}}$ is grants per capita, and the coefficients on the country dummies are not reported. 


\section{$\underline{\text { References }}$}

Baldwin, Richard, J. Francois, and R. Portes. 1997. "The Costs and Benefits of Eastern Enlargement: The Impact on the EU and Central Europe.” Economic Policy. April.

Besley, Timothy J. and Anne Case. 1995. "Incumbent Behavior: Vote-Seeking, Tax-Setting, and Yardstick Competition.” American Economic Review. 85: 25-45.

Besley, Timothy J. and Harvey Rosen. 1998. "Vertical Externalities in Tax Setting: Evidence from Gasoline and Cigarettes." Journal of Public Economics. (70) 3: 383-398.

Boadway, Robin and Michael Keen (1996). "Efficiency and Optimal Direction of Federal-State Transfers." International Tax and Public Finance. 3: 137-156.

Bond, Eric and Larry Samuelson. 1989. "Strategic Behavior and the Rules for International Taxation of Capital.” Economic Journal. 99: 1099-1111.

Cremer, Helmuth and Pierre Pestieau. 1996. "Distributive Implications of European Integration." European Economic Review. 40: 747-757.

Cremer, H., V. Fourgeaud, M.L. Montiero, M. Marchand, and P. Pestieau. 1995. "Mobility and Redistribution: A Survey." Mimeo.

Deininger, Klaus and Lyn Squire. 1996. "A New Data Set Measuring Income Inequality." World Bank Economic Review. 10: 565-591.

Edwards, Jeremy and Michael Keen. 1996. “Tax Competition and Leviathan.” European Economic Review. 40: 113-134.

Epple, D., R. Filimon, and T. Romer. 1984. "Equilibrium Among Jurisdictions: Toward an Integrated Treatment of Voting and Residential Choice." Journal of Public Economics. 24:281-308.

Epple, Dennis and Thomas Romer, 1991, "Mobility and Redistribution," Journal of Political Economy, pp. 828-858.

Fernandez, Raquel and Richard Rogerson. 1998. "Public Education and Income Distribution: A Dynamic Quantitative Evaluation of Education-Finance Reform." American Economic Review. 88: 813-833.

Fernandez, Raquel and Richard Rogerson. 1996. "Income Distribution, Communities, and the Quality of Education.” Quarterly Journal of Economics. 111: 135-164.

Giovannini, Alberto. 1990. "International Capital Mobility and Capital Income Taxation: Theory and Policy.” European Economic Review. 34: 480-488. 
Goodspeed, Timothy J. 1989. "A Re-Examination of the Use of Ability to Pay Taxes by Local Governments." Journal of Public Economics. 38: 319-342.

Goodspeed, Timothy J. 1995. "Local Income Taxation: An Externality, Pigouvian Solution, and Public Policies." Regional Science and Urban Economics. 25: 279-296.

Goodspeed, Timothy J. 1998. "On the Importance of Public Choice in Migration Models," Economics Letters. 59(3): 373-379.

Goodspeed, Timothy J. Forthcoming. “Tax Structure in a Federation.” Journal of Public Economics.

Gordon, Roger. 1986. "Taxation of Investment and Savings in a World Economy." American Economic Review. 76: 1087-1102.

Hettich, W. and S. Winer. 1988. "Economic and Political Foundations of Tax Structure." American Economic Review. 78: 701-712.

Keen, Michael. 1992. "Harmonization of Taxes on Capital Income." in P. Newman, M. Milgate, and J. Eatwell, eds., The New Palgrave Dictionary of Money and Finance.

Kristov, Lorenzo, Peter Lindert, and Robert McClelland. 1992. "Pressure Groups and Redistribution.” Journal of Public Economics. 48: 135-163.

Larin, Kathryn and Elizabeth McNichol. 1997. Pulling Apart: A State-by-State Analysis of Income Trends. Washington: Center on Budget and Policy Priorities.

Oates, Wallace E. 1972. Fiscal Federalism. New York: Harcourt, Brace, Jovanovich.

OECD 1986. Personal Income Tax Systems Under Changing Economic Conditions. Paris: OECD.

OECD. various years. Revenue Statistics of OECD Member Countries. Paris: OECD

OECD. 1989. Historical Statistics, 1960-1987. Paris: OECD.

Persson, Torsten and Guido Tabellini. 1992. "The Politics of 1992: Fiscal Policy and European Integration.” Review of Economic Studies. 59: 689-701.

Picketty, Thomas. 1996. "A Federal Voting Mechanism to Solve the Fiscal-Externality Problem." European Economic Review. 40: 3-17.

Razin, Assaf, and Efraim Sadka. 1991. "International Tax Competition and Gains from Tax Harmonization.” Economics Letters. 37: 69-76.

Sachs, Jeffrey and Xavier Sala-I-Martín. 1991. "Federal Fiscal Policy and Optimum Currency Area." 
Paper presented at CEPR/CGES/IMF Conference on Establishing a Central Bank.

Sinn, Hans-Werner. 1990. "Tax Harmonization and Tax Competition in Europe." European Economic Review. 34: 489-504.

Stigler, George. 1957. "The Tenable Range of Functions of Local Government." in Joint Economic Committee. Federal Expenditure Policy for Economic Growth and Stability. Washington: U.S. Government Printing Office.

Westhoff, Frank. 1977. "Existence of Equilibria in Economies with a Local Public Good," Journal of Economic Theory. 14: 84-112.

Wildasin, David. 1998. "Factor Mobility and Redistributive Policy: Local and International Perspectives." In P. B. Sorenson, ed., Public Finance in a Changing World. MacMillan Press.

Wildasin, David. 1996. "Introduction: Fiscal Aspects of Evolving Federations.” International Tax and Public Finance. 3: 121-135.

Wildasin, David. 1991. "Income Redistribution in a Common Labor Market." American Economic Review. (81) 4: 757-774.

Wildasin, David. 1989. "Interjurisdictional Capital Mobility: Fiscal Externality and a Corrective Subsidy." Journal of Urban Economics. 25: 193-212.

Wildasin, David. 1988. "Nash Equilibria in Models of Fiscal Competition." Journal of Public Economics. 35: 229-40.

Zodrow, George and Peter Miezskowski. 1986. "Pigou, Tiebout, Property Taxation, and the Underprovision of Local Public Goods." Journal of Urban Economics. 19: 296-315. 